\title{
Regulation of adrenomedullin release from human endothelial cells by sex steroids and angiotensin-II
}

\author{
Lachlan J Pearson, Christopher Rait, M Gary Nicholls ${ }^{\mathbf{1}}$, Timothy G Yandle ${ }^{\mathbf{1}}$ and John J Evans \\ Department of Obstetrics and Gynaecology and ${ }^{1}$ Department of Medicine, Christchurch School of Medicine and Health Sciences, University of Otago, \\ Christchurch, New Zealand \\ (Requests for offprints should be addressed to J J Evans; Email: john.evans@chmeds.ac.nz)
}

\begin{abstract}
It is well documented that there are gender differences in the incidence and patterns of cardiovascular diseases but the reasons are unclear. Sex steroids may modulate the behaviour of vascular endothelial cells, which in turn act by paracrine processes to alter adjacent vascular smooth muscle activity. We hypothesised that the sex steroids alter the percentage of vascular endothelial cells that secrete the vasodilator peptide, adrenomedullin and modify the adrenomedullin-stimulating action of angiotensin-II. The percentage of adrenomedullinsecreting human aortic endothelial cells was determined using the cell immunoblot method. Cells were incubated with selected concentrations of angiotensin-II, oestradiol and testosterone alone and sex steroids in combination with angiotensin-II. Adrenomedullin mRNA expression in endothelial cells was quantified by real-time PCR. It was observed that at $4 \mathrm{~h}$, angiotensin-II increased the percentage of
\end{abstract}

adrenomedullin-secreting cells in a concentration-dependent manner. Testosterone at physiological concentrations was observed to increase the number of adrenomedullin-secreting cells whilst oestradiol had no effect. Addition of testosterone to angiotensin-II resulted in less than additive increases in the number of cells secreting adrenomedullin. Oestradiol reduced the angiotensin-II-induced increase in adrenomedullinsecreting cells. Adrenomedullin mRNA expression was significantly increased by testosterone and there was also a trend for an increase in adrenomedullin mRNA expression, which occurred when cells were incubated with angiotensinII. Our results point to a complex interplay between the sex steroids and angiotensin-II in regulating adrenomedullin production by human endothelial cells, which may contribute to gender-related differences in vascular disease in humans.

Journal of Endocrinology (2006) 191, 171-177

\section{Introduction}

It is well established that there are gender-related differences in human vascular disease. Numerous studies have indicated that blood vessel contractility is sexually dimorphic and/or influenced by sex hormones (Orshal \& Khalil 2004) and both testosterone and oestradiol have a number of effects on the vasculature. Oestradiol has many reported vascular benefits in women, such as improving endothelial-dependent vasodilation (Pinto et al. 1997, Virdis et al. 2000) and regulation of cell proliferation (Farhat et al. 1996). However, clinical trials of oestradiol in postmenopausal women have provided equivocal evidence of benefit (Khalil 2005). Investigations regarding the actions of testosterone have produced contradictory results (Kravariti et al. 2005, Rosano et al. 2005). For example, both vasodilatory (Webb et al. 1999) and anti-vasodilatory effects have been observed (Hutchison et al. 1997, Ceballos et al. 1999) and testosterone may be involved in the development of some forms of experimental hypertension (Song et al. 2004, Reckelhoff 2005). Endothelial cells have receptors for both oestradiol (Losordo et al. 1994) and testosterone (Sierra-Ramirez et al. 2004), by which these steroids can directly influence blood vessels and hence the development of vascular disease and hypertension.

It is known that a complex network of neuroendocrine factors regulate blood vessel function and many input signals modulate the production and/or action of each factor (Isumi et al. 1998). One peptide, adrenomedullin, has demonstrated vasodilator effects in vitro as well as hypotensive actions in vivo (Kitamura et al. 1993, Nakamura et al. 1997). Adrenomedullin plasma levels are elevated in patients with essential hypertension, congestive heart failure and renal failure (Ishimitsu et al. 1994, Kitamura et al. 1994, Kato et al. 1996). Further, low-dose i.v. infusion of the hormone elicits clear biological effects at pathophysiologically relevant plasma levels (Lainchbury et al. 2000). Adrenomedullin is produced by a wide range of cell types, but plasma adrenomedullin appears to be derived mainly from endothelial cells, which have been reported to secrete large amounts of the peptide (Hinson et al. 2000, Beltowski \& Jamroz 2004). Therefore, identifying factors which act on endothelial cells to modify adrenomedullin secretion is of vital interest for defining blood vessel physiology and pathophysiology. In addition, adrenomedullin receptors have been detected on endothelial cells (Kato et al. 1995), suggesting that a complete 
understanding of adrenomedullin control may clarify paracrine and autocrine processes, which contribute to vascular structure, function and dysfunction.

Another peptide, angiotensin-II, is well known for its vasoconstrictor action. It has been reported that angiotensinII induces a rise in adrenomedullin levels in vivo (Onitsuka et al. 2005). Conversely, adrenomedullin inhibited the pressor activity of angiotensin-II (Charles et al. 2000, Luodonpaa et al. 2004) and also inhibited angiotensin-II-induced contraction in rat aortic rings, an action partially mediated by $\mathrm{NO}^{-}$ (Haulica et al. 2004). Hence, there appears to be indications of important physiological interactions between angiotensin-II and adrenomedullin (Charles et al. 2003). However, there are few studies that have investigated the interactions between adrenomedullin and angiotensin-II in endothelial cells.

In a previous study, it was reported that neither oestradiol nor testosterone influenced adrenomedullin mRNA levels in cultured rat aortic endothelial cells (Imai et al. 1995). On the other hand, both testosterone and oestradiol were shown to increase immunoreactive adrenomedullin secretion from rat aortic endothelial cells in culture (Isumi et al. 1998). We studied here the possible interaction between the two steroids, testosterone and oestradiol, with angiotensin-II and each separately in the modulation of adrenomedullin secretion. Although these compounds are concurrently present in blood vessels, their combined vascular effects are not established.

The cell immunoblot method, in which cells are incubated on a protein-binding membrane, has been extensively employed by our laboratory (Evans et al. 2002, 2003) and others (Arita 1993, Kusaka et al. 2000). The method uses singly dispersed cells, and in contrast to other methods in which cells are cultured in high density, is able to reduce effects of paracrine interactions, and can investigate functional diversity which may be present in endothelial cells (Frid et al. 2004). In this study, we used the cell immunoblot method to investigate whether testosterone, oestradiol and angiotensin-II, separately and together regulate adrenomedullin secretion at the level of the individual cell using human aortic endothelial cells.

\section{Materials and Methods}

\section{Human endothelial cells}

Human aortic endothelial cells were purchased (Clonetics, CA, USA) and cultured in endothelial basal medium (EBM) medium supplemented with endothelial growth medium (EGM) Bulletkit reagents (Cambrex, Walkersville, MD, USA). Cells were passaged on $10 \mathrm{~cm}$ collagen-coated dishes using trypsin/EDTA to release cells. Confluent cells at passages 7-9 were harvested using trypsin/EDTA and suspended in bicarbonate-free Dulbecco's modified Eagle medium (DMEM) medium containing $\mathrm{N}$-[2-hydroxyethyl]piperazine- $\mathrm{N}^{\prime}$ [2-ethanesulfonic acid] (HEPES) buffer $(\mathrm{pH} 7 \cdot 4)$ and $0 \cdot 1 \%$ BSA. The cells were used within $1 \mathrm{~h}$ of harvest.

\section{Cell immunoblot assay}

Immobilon $\mathrm{P}$ membrane (Millipore Corporation, Bedford, MA, USA), a protein-binding membrane, was cut into strips and immersed in methanol for $20 \mathrm{~s}$ and allowed to dry. Glass incubation cylinders (internal diameter and height, 5 and $9 \mathrm{~mm}$ respectively) were sealed to the membrane using silicon grease and the unit was transferred to humidified six-well culture dishes (well diameter $35 \mathrm{~cm}$ ). The membrane within each cylinder was incubated with $100 \mu \mathrm{D}$ DMEM for $15 \mathrm{~min}$ and then the medium was aspirated off. An aliquot of cells $(100 \mu \mathrm{l})$ was added and allowed to settle in the humidified chambers at $37^{\circ} \mathrm{C}$ for $60 \mathrm{~min}$. The supernatant was removed and discarded. Medium only or medium containing angiotensin-II (Bachem AG, Switzerland; $0 \cdot 0001-10 \mu \mathrm{M}$ ), testosterone (Sigma-Aldrich; 3.5-3500 nM) or $\beta$-oestradiol (Sigma-Aldrich; 0.0037$3700 \mathrm{nM}$ ) was then added. Combinations of angiotensin-II $(0 \cdot 01-10 \mu \mathrm{M})$ with oestradiol $(37 \mathrm{nM})$ or testosterone $(350 \mathrm{nM})$ added together were also used. The cells were incubated for $4 \mathrm{~h}$, after which the supernatant was removed. Glutaraldehyde (100 $\mu \mathrm{l}, 2 \cdot 5 \%$ (v/v); EM grade, ProSciTech) was added for $1 \mathrm{~h}$ at room temperature. The cells were washed $3 \times(10 \mathrm{~min}$ each $)$ in $100 \mu \mathrm{l}$ Tris- $\mathrm{HCl}$ buffer $(100 \mathrm{mM}, \mathrm{pH}$ $8 \cdot 2)$. Blocking buffer (Tris-HCl buffer containing 3\% BSA) was added for $1 \mathrm{~h}$ followed by $100 \mu \mathrm{l}$ rabbit anti-adrenomedullin antiserum $1 / 3000$ in Tris- $\mathrm{HCl}$ containing $0 \cdot 3 \%$ BSA. The cells were incubated overnight at $4{ }^{\circ} \mathrm{C}$ and then washed $3 \mathrm{X}$ in phosphate buffer ( $\mathrm{pH} 7 \cdot 4$ ) containing $0.3 \mathrm{M} \mathrm{NaCl}$ (PBS). Secondary antibody coupled to biotin (in PBS) was added at 1/1000 (goat anti-rabbit-IgG-biotin, Sigma-Aldrich) for $1 \mathrm{~h}$ and washed $3 \times$ in PBS. Adrenomedullin was visualised using alkaline phosphatase (Vectorstain kits, Vector Laboratories, Burlingame, CA, USA), which produced Vector Red product. Cells that secreted adrenomedullin were associated with a stained area on the Immobilon $\mathrm{P}$ membrane surrounding the cell. Control incubations were submitted to normal rabbit serum (Sigma-Aldrich) and to only secondary antibody to identify any non-specific binding.

The glass incubation cylinders were removed from the membrane strips. The membranes were passed through $70 \%$ ethanol, 100\% ethanol and xylene and rehydrated and the cells counterstained with light green CI42095 (Gurr, product no. $34204 ; 1 \%$ in water). The cells were dehydrated in increasing concentrations of ethanol, cleared in xylene and permanently mounted. The number of cells that secreted adrenomedullin was manually counted by two independent observers blinded to the treatments. Secretion was observed as colour development around the outside of the cell. The number of secreting cells was converted to a percentage of the total number of cells in the counted sample; approximately 300 cells were counted in each incubation. Each treatment was repeated in three incubations during each separate experiment. Results are presented as mean \pm s.E.M. For the dose-response studies of angiotensin-II and testosterone, the percentage of cells that secreted adrenomedullin in the groups at each concentration were compared to the results in incubations without added 
peptide and statistically analysed by Student's $t$-test. The data were treated as a single set and submitted to the paired $t$-test in the experiment in which cells were exposed to testosterone that was added to angiotensin-II (incubations with angiotensin-II versus incubations with angiotensin-II + testosterone). Results of $P<0 \cdot 05$ were taken to indicate a statistically significant difference between groups.

\section{Adrenomedullin RIA}

The adrenomedullin RIA was based on the work of Lewis et al. (1998). Human aortic endothelial cells were grown in EGM-2 growth media to approximately $90 \%$ confluence in six-well plates. A $1 \mathrm{~h}$ preincubation of cells in serum-free DMEM $0 \cdot 1 \%$ BSA was performed. The media were then replaced with fresh DMEM $0 \cdot 01 \%$ BSA with or without either angiotensin-II $(1 \mu \mathrm{M})$ or testosterone $(100 \mathrm{ng} / \mathrm{ml})$. After $4 \mathrm{~h}$, the media were collected and immediately acidified with acetic acid ( $1 \mathrm{M})$. Triton-X $0 \cdot 001 \%$ was added and the solution was boiled for $10 \mathrm{~min}$. The samples were stored at $-20{ }^{\circ} \mathrm{C}$ and were thawed and centrifuged, and supernatants mixed with an equal volume of $0 \cdot 1 \%$ Triton-X. Samples were added under gravity to Sep-Pak $\mathrm{C}_{18}$ cartridges (Waters) and washed with $0.9 \%$ saline under low pressure $(<17 \mathrm{kPa})$. Adrenomedullin was eluted with $2 \mathrm{ml}$ of $80 \%$ isopropanol/ $0 \cdot 013 \mathrm{M} \mathrm{HCl}$ into tubes containing $10 \mu \mathrm{l}$ of $1 \%$ Triton. Tubes were air-dried and stored at $-20^{\circ} \mathrm{C}$ until assayed. Extracts were reconstituted with $300 \mu \mathrm{l}$ phosphate-alkali treated casein (PATC) buffer and centrifuged. Antiserum and I-labelled adrenomedullin were added on ice, and the tubes were incubated at $4{ }^{\circ} \mathrm{C}$ for $24 \mathrm{~h}$. Bound and free fractions were separated using secondary antibody. After centrifugation, the pellet was counted for radioactivity. Results were interpolated from a computer-fitted standard curve.

\section{Real-time PCR}

Human aortic endothelial cells were grown to approximately 90\% confluence on six-well plates in EGM. One hour prior to the experiment, the medium was replaced with serum-free DMEM $0 \cdot 1 \%$ BSA. At time zero, cells were incubated in fresh DMEM $0 \cdot 1 \%$ BSA without or with testosterone $(350 \mathrm{nM})$ or angiotensin-II $(1 \mu \mathrm{M})$. At time points $-1,0$, 1 and 3 h, RNA was extracted using the RNeasy Mini Kit (Qiagen) as specified in the RNeasy mini handbook. Concurrently, other cells were incubated in unchanged EGM in the presence or in the absence of testosterone before RNA extraction at $3 \mathrm{~h}$. Cells were washed with physiological PBS, lysed in lysis buffer provided in the kit, removed from the plate with a cell scraper and homogenised using a syringe and needle. Homogenate was mixed with $70 \%$ ethanol and added to RNeasy mini columns. RNA was eluted with $40 \mu \mathrm{l}$ water. RNA quantity and purity were analysed with a spectrophotometer (ND-1000, NanoDrop). Agarose gel electrophoresis was performed to test for RNA degradation. All RNA was diluted to $27 \mathrm{ng} / \mu \mathrm{l}$ and reverse transcribed with a blend of oligo-dT and random primers (Qiagen) in a Thermal Cycler (Palm Cycler, Corbett Research). cDNA levels were measured and diluted to under $50 \mathrm{ng} / \mu \mathrm{l}$. Semiquantitative PCR using Syber Green PCR kit (Qiagen) was performed with a real-time DNA amplification system (Rotagene 3000, Corbett Research). Bioinformatically validated primers included a housekeeping gene glyceraldehyde-3-phosphate dehydrogenase (Qiagen Cat no. QT 00079247) and adrenomedullin (Qiagen Cat no. QT00223846). Product purity was checked with a melt curve and $\mathrm{Ct}$ values were derived using Rotagene 3000 software (Corbett Research). A standard curve was generated from RNA extracted from human aortic endothelial cells. Both genes had amplification efficiencies greater than 0.9 and had linear logarithmic concentration curves with regression coefficients greater than $0 \cdot 98$. The $\mathrm{Ct}$ method was selected for analysis of samples as stated in the Quantitect Primer Assay Handbook (Qiagen). All PCRs were performed in at least duplicate. Controls included a no template control and negative control.

\section{Results}

Approximately, one-tenth $(9 \cdot 7 \pm 0 \cdot 7 \%)$ of the endothelial cells in basal medium were observed to secrete the vasodilatory peptide, adrenomedullin, during the $4 \mathrm{~h}$ incubation period. Exposure of the cells to angiotensin-II for $4 \mathrm{~h}$ induced an increase in the number of adrenomedullinsecreting cells in a concentration-dependent manner (Fig. 1). A significant increase was observed at $1 \mathrm{nM}$ angiotensin-II.

Testosterone added to the incubation medium likewise caused an increase in the numbers of cells secreting adrenomedullin in a concentration-dependent manner (Fig. 2). In contrast, oestradiol had no significant effect on

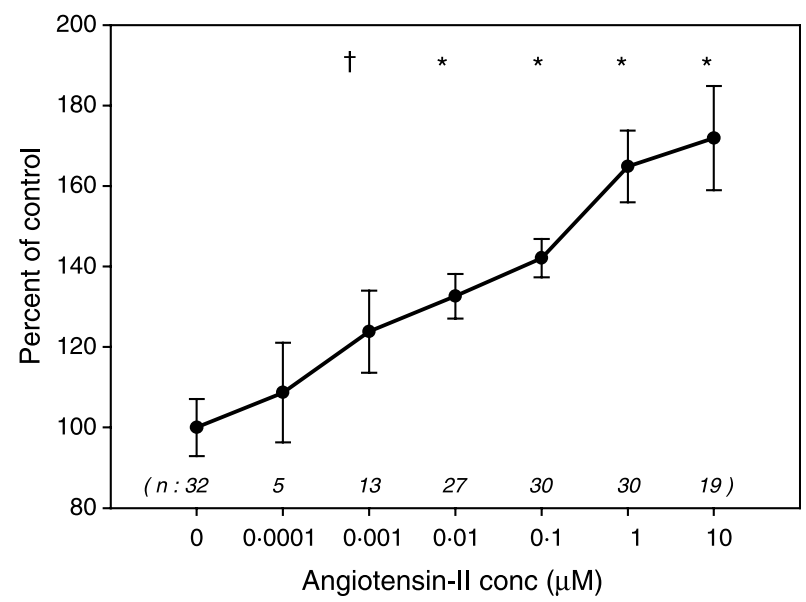

Figure 1 The effect of increasing concentrations of angiotensin-Il on the percentage of endothelial cells that secreted adrenomedullin after $4 \mathrm{~h}$ incubation. A concentration-dependent effect was observed $\left({ }^{*} P<0 \cdot 001 ;{ }^{+} P<0 \cdot 05\right.$ compared with control incubations performed in the absence of angiotensin-II). 


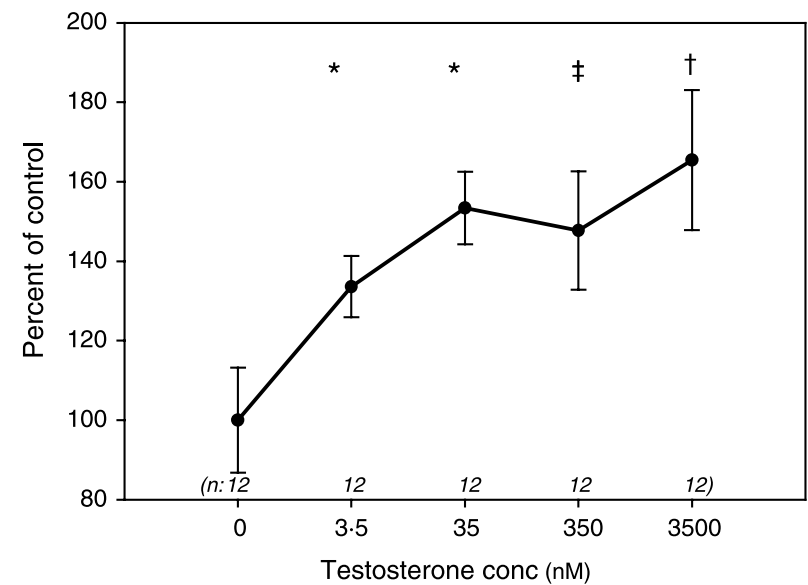

Figure 2 The effect of increasing concentrations of testosterone on the percentage of endothelial cells that secreted adrenomedullin after $4 \mathrm{~h}$ incubation. A concentration-dependent effect was observed $\left({ }^{*} P<0 \cdot 001 ;{ }^{\dagger} P<0 \cdot 01 ;{ }^{\ddagger} P<0 \cdot 05\right.$ compared with control incubations performed in the absence of testosterone).

the percentage of cells in basal medium that secreted adrenomedullin (Fig. 3). Treatment of endothelial cells with testosterone and angiotensin-II together significantly increased the percentage of cells that secreted adrenomedullin compared to that with angiotensin-II alone $(P<0 \cdot 05$; Fig. 4). The increases induced by angiotensin-II and testosterone in combination were less than additive compared to their independent actions. On the other hand, oestradiol exhibited a significant inhibition on the stimulatory effect of angiotensin-II $(n=14$, paired $t$-test, $P<0 \cdot 05)$.

RIAs of the supernatants of incubated endothelial cells confirmed the release of adrenomedullin under basal conditions ( $22 \mathrm{fmole} / 10^{6}$ cells) at $4 \mathrm{~h}$, but no significant changes in adrenomedullin concentrations were observed following exposure to testosterone, oestradiol or angiotensin-II.

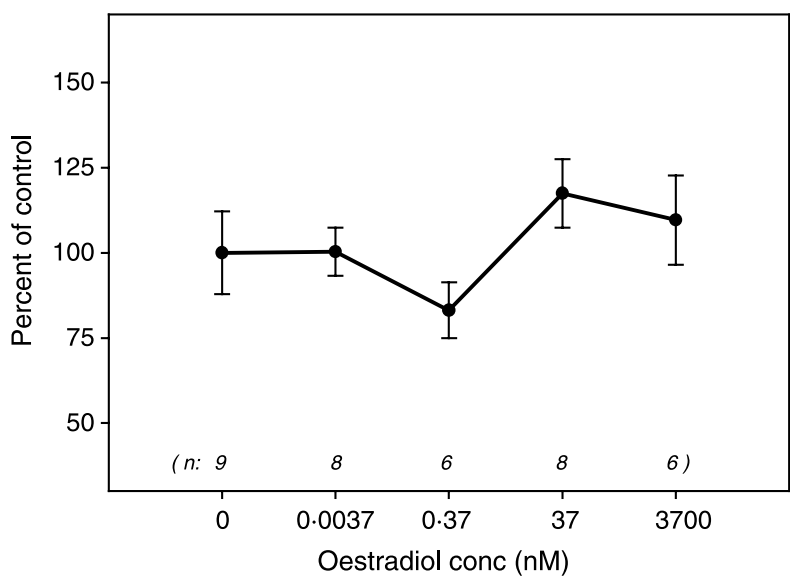

Figure 3 No significant effect of a series of concentrations of oestradiol was observed on the percentage of endothelial cells that secreted adrenomedullin after $4 \mathrm{~h}$ incubation.

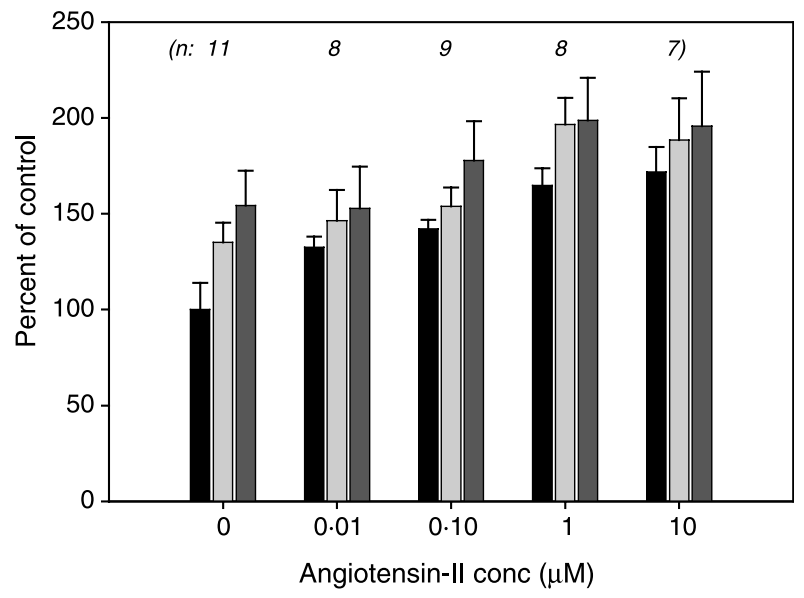

Figure 4 The effect of angiotensin alone and in combination with testosterone on the percentage of endothelial cells that secreted adrenomedullin. Dark bar, angiotensin-II only (at $0 \mu \mathrm{M}$ the incubation contained medium only); light grey bar, angiotensin-II+ testosterone $3.5 \mathrm{nM}$; medium grey bar, angiotensin-II + testosterone $350 \mathrm{nM}$. The addition of testosterone to angiotensin-II increased the percentage of cells that secreted adrenomedullin over that induced by angiotensin-II alone $(P<0 \cdot 05$, paired $t$-test $)$ in a manner that was less than additive.

To investigate whether there were effects on other processes in the cell, reverse transcriptase-PCR was performed after endothelial cells had been exposed to angiotensin-II $(1 \mu \mathrm{M})$ or testosterone $(350 \mathrm{nM})$. In concert with the observation that both the peptide and the sex steroid increased the number of cells that secreted adrenomedullin, both hormones induced an increase in the mean level of expression of adrenomedullin mRNA (Fig. 5), the effect being statistically significant for testosterone.

\section{Discussion}

This investigation examined the effects on adrenomedullin secretion of angiotensin-II and sex steroids in human aortic endothelial cells. Adrenomedullin has been recognised to have potent vasodilatory activity (Ishimitsu et al. 1994, Kitamura et al. 1994, Kato et al. 1996, Lainchbury et al. 2000). However, its interactions at the level of the endothelial cells with other vasoactive hormones remain to be defined. In contrast to adrenomedullin, angiotensin-II has potent vasoconstricting activity. In that, there is a clear epidemiological data, indicating gender differences in vascular disease, we hypothesised that peptides which influence vascular tone, namely angiotensin-II and adrenomedullin, may interact with sex steroids.

We showed that incubation with testosterone at concentrations as low as $3 \cdot 5 \mathrm{nM}$ over $4 \mathrm{~h}$ increased the proportion of cells that secreted adrenomedullin. This concentration is within the physiological range for testosterone in the plasma of healthy males $(10-30 \mathrm{nM})$. Our results, showing that 


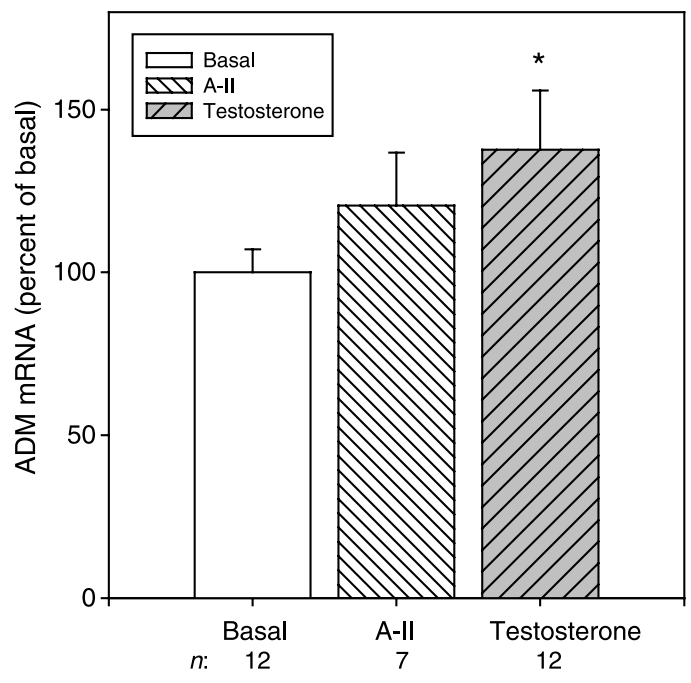

Figure 5 The effects of angiotensin-II or testosterone on adrenomedullin mRNA expression. The mRNA expression was determined relative to a housekeeping gene (GADPH) and the levels in cells exposed to hormone were calculated as a percentage of the expression in control incubations without hormone. An increase in mean adrenomedullin mRNA was observed in incubations with testosterone $\left({ }^{*} P=0 \cdot 05\right.$, paired $t$-test $)$ and angiotensin-II.

testosterone increases the number of cells secreting adrenomedullin, reveal that testosterone has a direct effect on endothelial cells. Furthermore, it appears that the effect of testosterone on the vascular system may have an indirect component through the secretion of this vasodilator peptide. These results may partly explain observations that there is an inverse relationship between testosterone concentrations and blood pressure in men and that there can be beneficial effects of testosterone on the vasculature (Khaw \& Barrett-Connor 1988, Jones et al. 2004).

By contrast, oestradiol had no detectable effect on the numbers of cells that secreted adrenomedullin. This may reflect a true absence of any effect or alternatively oestradiol may have effects outside the time parameter used in this study. The latter possibility is supported by investigations of other vascular systems, including prostacyclin production in endothelial cells (Mikkola et al. 1995) and AT1 receptor gene expression in smooth muscle cells (Nickenig et al. 1998), which have revealed that oestradiol may have a maximum effect at $12 \mathrm{~h}$ or greater. Endothelial cells can convert testosterone to oestradiol (Mukherjee et al. 2002) and it has been suggested that effects attributed to testosterone may be in part a result of its conversion to oestradiol (Sierra-Ramirez et al. 2004). However, our observation that testosterone increased the number of adrenomedullin-secreting endothelial cells, and that oestradiol had no significant effect, indicates that the actions of testosterone exhibited here were unlikely to be dependent on its conversion to oestradiol.

Angiotensin-II caused an increase in the number of adrenomedullin-secreting cells in a concentration-dependent manner. In this study, a significant increase in adrenomedullin-secreting cells was detected at $0 \cdot 001 \mu \mathrm{M}$ angiotensin and maximum stimulation was observed at about $1 \mu \mathrm{M}$. Previous experiments in our laboratory have indicated that endothelin-1 increases the number of cells secreting adrenomedullin (Evans et al. 2002). It is evident therefore that adrenomedullin is released from endothelial cells in response to two potent vasoconstrictors, angiotensin-II and endothelin-1. In that some actions of angiotensin-II are via stimulation of endothelin-1 (Riggleman et al. 2001, Pollock 2005), it is possible that the adrenomedullin response to angiotensin-II observed in the present study resulted from augmented endothelin-1 production in endothelial cells.

Although we observed the number of endothelial cells secreting adrenomedullin increased following exposure to testosterone or angiotensin-II, over the same time period, RIA did not detect a global change in the amounts of adrenomedullin released. This observation suggests that paracrine effects in situ between neighbouring endothelial cells and endothelial and smooth muscle cells may occur and have a role in the physiological regulation of vascular behaviour yet remain undetected when conventional methods, such as RIA, are used to determine the magnitude of hormone responses.

Our investigations regarding the effect of hormones on adrenomedullin mRNA levels were consistent with angiotensin-II and testosterone enhancing the production of ADM via increased mRNA expression as well as its secretion from endothelial cells. The results in relation to mRNA in this study were somewhat more robust for testosterone than angiotensin-II. Our data are at variance with others (Imai et al. 1995) who utilised Northern blotting and reported that testosterone did not have a detectable effect on adrenomedullin mRNA expression in endothelial cells. The reasons behind this discrepancy are not immediately apparent but could relate to different experimental circumstances or differences regarding the origin of the endothelial cells.

To our knowledge, this is the first study to investigate in vitro interactions between sex hormones and angiotensin-II on adrenomedullin release from endothelial cells, in the absence of other blood-borne factors that could complicate interpretation. The cell immunoblot method enables direct cellular responses to stimulation to be investigated. The method is very sensitive, detecting small changes in secretion from single cells within a population over relatively short time periods. Changes have been reported using the cell immunoblot within $1 \mathrm{~h}$ for secretion of angiotensin-II and endothelin-1 by endothelial cells (Kusaka et al. 2000). Vascular peptide measurements in vitro following exposure to compounds of interest have often used longer incubation periods prior to RIA (Isumi et al. 1998, Tomoda et al. 2001), and interpretation of the amount of peptide in the supernatant is potentially confounded by protein degradation or feedback processes acting on the cell. Clearly, the cell immunoblot methodology provides information that may be difficult or impossible to obtain by other techniques. 
We conclude that testosterone increases the percentage of human endothelial cells that secrete adrenomedullin. Our results support the notion that testosterone may contribute to vasodilatory responses, partially through the release of adrenomedullin by endothelial cells. However, in the conditions of this study oestradiol had no significant effect on the number of adrenomedullin-secreting cells. Angiotensin-II recruited cells to the adrenomedullin-secreting population, and since angiotensin-II is produced by endothelial cells (Kifor \& Dzau 1987, Kusaka et al. 2000), it may act in a paracrine/autocrine manner in regulating adrenomedullin release in the complex network that modulates vascular tone and growth.

\section{Acknowledgements}

The support of the NZ Heart Foundation, the Canterbury Medical Research Foundation and the NZ Lottery Health Board are gratefully acknowledged. The assistance of Associate Professor Elisabeth Wells in the statistical analysis was much appreciated. The authors declare that there is no conflict of interest that would prejudice the impartiality of this scientific work.

\section{References}

Arita J 1993 Analysis of the secretion from single anterior pituitary cells by cell immunoblot assay. Endocrine Journal 40 1-15.

Beltowski J \& Jamroz A 2004 Adrenomedullin - what do we know 10 years since its discovery? Polish Journal of Pharmacology 56 5-27.

Ceballos G, Figueroa L, Rubio I, Gallo G, Garcia A, Martinez A, Yanez R, Perez J, Morato T \& Chamorro G 1999 Acute and nongenomic effects of testosterone on isolated and perfused rat heart. Journal of Cardiovascular Pharmacology 33 691-697.

Charles CJ, Rademaker MT, Richards AM, Cooper GJ, Coy DH \& Nicholls MG 2000 Adrenomedullin attenuates pressor response to angiotensin II in conscious sheep. Journal of Cardiovascular Pharmacology 36 526-532.

Charles CJ, Lainchbury JG, Nicholls MG, Rademaker MT, Richards AM \& Troughton RW 2003 Adrenomedullin and the renin-angiotensinaldosterone system. Regulatory Peptides 112 41-49.

Evans JJ, Youssef AH, Yandle TG, Lewis LK \& Nicholls MG 2002 Effects of endothelin-1 on release of adrenomedullin and C-type natriuretic peptide from individual human vascular endothelial cells. Journal of Endocrinology 175 225-232

Evans JJ, Youssef AH, Yandle TG, Lewis LK \& Nicholls MG 2003 Endothelin-1 directly modulates its own secretion: studies utilising the cell immunoblot technique. Regulatory Peptides 113 149-153.

Farhat MY, Lavigne MC \& Ramwell PW 1996 The vascular protective effects of estrogen. FASEB Journal 10 615-624.

Frid MG, Aldashev AA, Crossno JT, Jorgensen JM, Kale VA \& Stenmark KR 2004 Yin and Yang of an endothelial cell: from normal to the extreme in growth, secretion, and transdifferentiation capabilities. Paediatric Respiratory Reviews 5 S253-S257.

Haulica I, Bild W, Mihaila C, Serban DN, Serban L, Boisteanu D, Ionita T \& Radasanu O 2004 Comparative study of the inhibitory effects of adrenomedullin on angiotensin II contraction in rat conductance and resistance arteries. Journal of the Renin-Angiotensin-Aldosterone System $\mathbf{5}$ 79-83.

Hinson JP, Kapas S \& Smith DM 2000 Adrenomedullin, a multifunctional regulatory peptide. Endocrine Reviews 21 138-167.
Hutchison SJ, Sudhir K, Chou TM, Sievers RE, Zhu BQ, Sun YP, Deedwania PC, Glantz SA, Parmley WW \& Chatterjee K 1997

Testosterone worsens endothelial dysfunction associated with hypercholesterolemia and environmental tobacco smoke exposure in male rabbit aorta. Journal of the American College of Cardiology 29 800-807.

Imai T, Hirata Y, Iwashina M \& Marumo F 1995 Hormonal regulation of rat adrenomedullin gene in vasculature. Endocrinology 136 1544-1548.

Ishimitsu T, Nishikimi T, Saito Y, Kitamura K, Eto T, Kangawa K, Matsuo H, Omae T \& Matsuoka H 1994 Plasma levels of adrenomedullin, a newly identified hypotensive peptide, in patients with hypertension and renal failure. Journal of Clinical Investigation 94 2158-2161.

Isumi Y, Shoji H, Sugo S, Tochimoto T, Yoshioka M, Kangawa K, Matsuo H \& Minamino N 1998 Regulation of adrenomedullin production in rat endothelial cells. Endocrinology 139 838-846.

Jones RD, Hugh Jones T \& Channer KS 2004 The influence of testosterone upon vascular reactivity. European Journal of Endocrinology 151 29-37.

Kato J, Kitamura K, Kangawa K \& Eto T 1995 Receptors for adrenomedullin in human vascular endothelial cells. European Journal of Pharmacology 289 383-385.

Kato J, Kobayashi K, Etoh T, Tanaka M, Kitamura K, Imamura T, Koiwaya Y, Kangawa K \& Eto T 1996 Plasma adrenomedullin concentration in patients with heart failure. Journal of Clinical Endocrinology and Metabolism $\mathbf{8 1}$ 180-183.

Khalil RA 2005 Sex hormones as potential modulators of vascular function in hypertension. Hypertension 46 249-254.

Khaw KT \& Barrett-Connor E 1988 Blood pressure and endogenous testosterone in men: an inverse relationship. Journal of Hypertension 6 329-332.

Kifor I \& Dzau VJ 1987 Endothelial renin-angiotensin pathway: evidence for intracellular synthesis and secretion of angiotensins. Circulation Research $\mathbf{6 0}$ $422-428$.

Kitamura K, Kangawa K, Kawamoto M, Ichiki Y, Nakamura S, Matsuo H \& Eto T 1993 Adrenomedullin: a novel hypotensive peptide isolated from human pheochromocytoma. Biochemical and Biophysical Research Communications 192 553-560.

Kitamura K, Ichiki Y, Tanaka M, Kawamoto M, Emura J, Sakakibara S, Kangawa K, Matsuo H \& Eto T 1994 Immunoreactive adrenomedullin in human plasma. FEBS Letters 341 288-290.

Kravariti M, Naka KK, Kalantaridou SN, Kazakos N, Katsouras CS, Makrigiannakis A, Paraskevaidis EA, Chrousos GP, Tsatsoulis A \& Michalis LK 2005 Predictors of endothelial dysfunction in young women with polycystic ovary syndrome. Journal of Clinical Endocrinology and Metabolism 2828.

Kusaka Y, Kelly RA, Williams GH \& Kifor I 2000 Coronary microvascular endothelial cells cosecrete angiotensin II and endothelin-1 via a regulated pathway. American Journal of Physiology 279 H1087-H1096.

Lainchbury JG, Troughton RW, Lewis LK, Yandle TG, Richards AM \& Nicholls MG 2000 Hemodynamic, hormonal, and renal effects of shortterm adrenomedullin infusion in healthy volunteers. Journal of Clinical Endocrinology and Metabolism 85 1016-1020.

Lewis LK, Smith MW, Yandle TG, Richards AM \& Nicholls MG 1998 Adrenomedullin(1-52) measured in human plasma by radioimmunoassay: plasma concentration, adsorption, and storage. Clinical Chemistry 44 571-577.

Losordo DW, Kearney M, Kim EA, Jekanowski J \& Isner JM 1994 Variable expression of the estrogen receptor in normal and atherosclerotic coronary arteries of premenopausal women. Circulation 89 1501-1510.

Luodonpaa M, Leskinen H, Ilves M, Vuolteenaho O \& Ruskoaho H 2004 Adrenomedullin modulates hemodynamic and cardiac effects of angiotensin II in conscious rats. American Journal of Physiology 286 R1085-R1092.

Mikkola T, Turunen P, Avela K, Orpana A, Viinikka L \& Ylikorkala O 1995 17 beta-estradiol stimulates prostacyclin, but not endothelin-1, production in human vascular endothelial cells. Journal of Clinical Endocrinology and Metabolism 80 1832-1836.

Mukherjee TK, Dinh H, Chaudhuri G \& Nathan L 2002 Testosterone attenuates expression of vascular cell adhesion molecule- 1 by conversion to estradiol by aromatase in endothelial cells: implications in atherosclerosis. PNAS 99 4055-4060. 
Nakamura M, Yoshida H, Makita S, Arakawa N, Niinuma H \& Hiramori K 1997 Potent and long-lasting vasodilatory effects of adrenomedullin in humans. Comparisons between normal subjects and patients with chronic heart failure. Circulation 95 1214-1221.

Nickenig G, Baumer AT, Grohe C, Kahlert S, Strehlow K, Rosenkranz S, Stablein A, Beckers F, Smits JF, Daemen MJ, Vetter H \& Bohm M 1998 Estrogen modulates AT 1 receptor gene expression in vitro and in vivo. Circulation 97 2197-2201.

Onitsuka H, Imamura T, Yamaga J, Kuwasako K, Kitamura K \& Eto T 2005 Angiotensin II stimulates cardiac adrenomedullin production and causes accumulation of mature adrenomedullin independently of hemodynamic stress in vivo. Hormone and Metabolic Research 37 281-285.

Orshal JM \& Khalil RA 2004 Gender, sex hormones, and vascular tone. American Journal of Physiology 286 R233-R249.

Pinto S, Virdis A, Ghiadoni L, Bernini G, Lombardo M, Petraglia F, Genazzani AR, Taddei S \& Salvetti A 1997 Endogenous estrogen and acetylcholine-induced vasodilation in normotensive women. Hypertension $29268-273$.

Pollock DM 2005 Endothelin, angiotensin, and oxidative stress in hypertension. Hypertension 45 477-480.

Reckelhoff JF 2005 Sex steroids, cardiovascular disease, and hypertension: unanswered questions and some speculations. Hypertension 45 170-174.

Riggleman A, Harvey J \& Baylis C 2001 Endothelin mediates some of the renal actions of acutely administered angiotensin II. Hypertension $\mathbf{3 8}$ 105-109.
Rosano GM, Cornoldi A \& Fini M 2005 Effects of androgens on the cardiovascular system. Journal of Endocrinological Investigation 28 32-38.

Sierra-Ramirez A, Morato T, Campos R, Rubio I, Calzada C, Mendez E \& Ceballos G 2004 Acute effects of testosterone on intracellular $\mathrm{Ca}_{2}{ }^{+}$kinetics in rat coronary endothelial cells are exerted via aromatization to estrogens. American Journal of Physiology 287 H63-H71.

Song D, Arikawa E, Galipeau D, Battell M \& McNeill JH 2004 Androgens are necessary for the development of fructose-induced hypertension. Hypertension 43 667-672.

Tomoda Y, Isumi Y, Katafuchi T \& Minamino N 2001 Regulation of adrenomedullin secretion from cultured cells. Peptides 22 1783-1794.

Virdis A, Ghiadoni L, Pinto S, Lombardo M, Petraglia F, Gennazzani A, Buralli S, Taddei S \& Salvetti A 2000 Mechanisms responsible for endothelial dysfunction associated with acute estrogen deprivation in normotensive women. Circulation 101 2258-2263.

Webb CM, McNeill JG, Hayward CS, de Zeigler D \& Collins P 1999 Effects of testosterone on coronary vasomotor regulation in men with coronary heart disease. Circulation 100 1690-1696.

Received 14 February 2006

Received in final form 8 June 2006

Accepted 20 June 2006

Made available online as an Accepted Preprint 24 July 2006 